\title{
IMPLEMENTASI PEDOMAN PERILAKU PENYIARAN MENURUT PERSPEKTIF KOMISI PENYIARAN INDONESIA (KPI)
}

\author{
Dominikus Tulasi \\ Marketing Communication Department, Faculty of Economic and Communication, BINUS University \\ Jln. K.H. Syahdan No.9, Palmerah, Jakarta Barat 11480 \\ dtulasi@binus.edu
}

\begin{abstract}
This multidiscipline research combines models and theoretical guidance of Indonesia Broadcasting Commission in implementing ethical behavioral guidance toward television broadcasting programs as mass media, a case study at Trans7. This qualitative research examined on how both Television management and Indonesia Broadcasting Commission highlight and perceive behavioral acting of host relating to entertainment programs. In one hand, program producer is able to construct, construe, and reconstruct societal opinions and mindset to its program. On the other hand, Indonesia Broadcasting Commission (KPI) construes the television program overacting and unethical. KPI judges the behavior of the program host does not deserve to present to the society referring to the broadcasting regulations, especially broadcasting behavioral guidance and broadcasting program standard (P3-SPS). Analyzing the implications television broadcasting program is a matter of negative image towards national culture and social norms through significant participant observation. This phenomenon is alarming, considering the host of TV programs which in the long run will be able to influence social value system and national culture. As it is able to gain an extensive understanding towards the identity makeup and sense of television broadcasting programs that exist within Indonesian society.
\end{abstract}

Keywords: Indonesia Broadcasting Commission, broadcasting behavioral guidance, broadcasting program standard, broadcasting programs

\begin{abstract}
ABSTRAK
Penelitian ini bersifat multidisiplin yang mengombinasikan beragam model sebagai petunjuk untuk Komisi Penyiaran Indonesia dalam menerapkan pedoman perilaku beretika terhadap program televisi sebagai media massa, khususnya Trans7. Penelitian kualitatif ini meneliti bagaimana manajemen televisi dan Komisi Penyiaran Indonesia menyoroti dan melihat perilaku akting host yang terkait dengan program hiburan. Di satu sisi, produser program ini mampu membangun, menafsirkan, dan merekonstruksi pendapat sosial, dan pola pikir untuk programnya. Di sisi lain, Komisi Penyiaran Indonesia (KPI) menafsirkan program televisi berlebihan dan tidak etis. KPI menilai perilaku host program tidak layak menyajikan kepada masyarakat mengacu pada peraturan penyiaran, khususnya Pedoman Perilaku Penyiaran dan Standar Program Standar (P3-SPS). Menganalisis program penyiaran televisi implikasi adalah masalah citra negatif terhadap budaya nasional dan norma-norma sosial melalui observasi partisipan signifikan. Fenomena ini mengkhawatirkan , mengingat sejumlah program TV yang dalam jangka panjang akan dapat memengaruhi sistem nilai sosial dan budaya nasional. Hal yang demikian mampu memperoleh pemahaman yang luas terhadap identitas riasan dan rasa program siaran televisi yang ada di masyarakat Indonesia.
\end{abstract}

Kata kunci: Komisi Penyiaran Indonesia, Pedoman Perilaku Penyiaran, Standar Program Siaran, program siaran 


\section{PENDAHULUAN}

Komisi Penyiaran Indonesia (KPI) adalah sebuah lembaga negara independen yang bertugas dan berfungsi mengawasi program penyiaran khususnya program siaran televisi. Program-program siaran televisi yang diharapkan KPI adalah tayangan program televisi yang sesuai dengan kandungan dari Pedoman Perilaku Penyiaran (P3) dan Standar Program Siaran (SPS) tahun 2012. Hal tersebut sesuai dengan prinsip-prinsip Jurnalistik Umum pasal 22, ayat (1) yakni: Lembaga penyiaran wajib menjalankan dan menjunjung tinggi idealisme jurnalistik yang menyajikan informasi untuk kepentingan publik dan pemberdayaan masyarakat, membangun dan menegakkan demokrasi, mencari kebenaran, melakukan koreksi dan kontrol sosial, dan bersikap independen. Sedangkan ayat (2) lembaga penyiaran wajib menjunjung tinggi prinsip-prinsip jurnalistik, antara lain: akurat berimbang, adil tidak beritikat buruk, tidak menghasut dan menyesatkan, tidak mencampuradukkan fakta dan opini pribadi, tidak menonjolkan unsur sadistis, tidak mempertentangkan suku, agama, ras dan antargolongan, serta tidak membuat berita bohong, fitnah, dan cabul.

Prinsip-prinsip jurnalistik sesuai petunjuk dua pasal yang disebutkan, mengandung makna denotatif bahwa unsur-unsur dinamika keberagaman merupakan faktor utama dan terpenting didalam prinsip jurnalisme. Hal tersebut dipertegas lebih lanjut pada ayat (3) yang berbunyi lembaga penyiaran dalam melaksanakan kegiatan jurnalistik "wajib" tunduk pada peraturan perundang-undangan yang berlaku serta pedoman perilaku penyiaran dan standar program siaran. Penulis sengaja memberi tanda petik pada kata wajib untuk menegaskan bahwa ayat tersebut menekankan pentingnya menaati pedoman perilaku penyiaran. Makna implisit yang merupakan suatu "noumena" melekat jelas pada kata wajib, yakni tanpa kecuali harus ditaati. Kenyataan implementasi di lapangan justru menampilkan yang sebaliknya. Khusus perilaku host program televisi yang berhak secara langsung tampil menjamu bintang tamu suatu program diharapkan memahami dan mematuhi rambu-rambu petunjuk penyiaran, baik secara live maupun tayangan dalam bentuk rekaman. Dalam kenyataan, masyarakat pemirsa menyaksikan perilaku dari host program tertentu yang sangat tidak mendidik.

Pedoman pelarangan adegan ekspresi seksual misalnya justru sangat digemari oleh host program tertentu untuk disajikan bagi pemirsa tanpa memerhatikan nilai-nilai yang dianut masyarakat pada umumnya. Padahal KPI sebagai lembaga pengontrol program tayang dan standar program siaran sudah secara normatif melarangnya. Pelarangan yang terkait adegan ekspresi seksual dengan tegas dinyatakan secara eksplisit pada pasal 18 point d, menyatakan: "menampilkan suara yang menggambarkan berlangsungnya aktivitas seks dan/atau persenggamaan.” Pelarangan lebih lanjut tentang unsur mengandung seks terlihat jelas pada butir h, yang berbunyi: "mengeksploitasi dan/atau menampilkan bagian-bagian tubuh tertentu, seperti: paha, bokong, payudara, secara close up dan/atau medium shot;" diperkuat regulasi adegan pada butir i, "menampilkan gerakan tubuh dan/atau tarian erotis.” Pertanyaan dasarnya mengapa tumpukan regulasi penyiaran yang secara eksplisit diberlakukan, kenyataan di lapangan bisa berlangsung tanpa sensor dan vulgar; siapa yang harus bertanggung jawab mengenai implementasi pedoman perilaku penyiaran dan standar program siaran. Jawaban ringkas tentu Komisi Penyiaran Indonesia, namun pertanyaan berlanjut, adilkah beban sensor perilaku penyiaran program sepenuhnya berada di pundak KPI. Tentu saja sangat tidak adil melepas tanggung jawab kepada pembuat regulasi semata. Persoalannya adalah bahwa tidak semua pembawa acara (host) televisi memahami kandungan pedoman perilaku penyiaran. Jika memahami, mereka selalu mengabaikannya karena host atau produser lebih berorientasi pada market needs atau selera pemirsa, demi menaikkan 'rating' penyiaran.

Hal yang diamati dan dicermati adalah bahwa tidak semua host program televisi memiliki kapasitas yang cukup untuk tampil secara elegan dan terdidik. Penyebabnya adalah ketidakpahaman host bagaimana seharusnya mengaplikasikan suatu regulasi sebagai pedoman. Host atau pembawa acara adalah manusia-manusia induktif yang dipersiapkan produser untuk menjawab kebutuhan pasar. 
Dengan kata lain, produser program maupun manajemen televisi lebih berorientasi profit, daripada menjaga nilai-nilai yang dianut masyarakat. Tengok misalnya tayangan-tayangan selama bulan puasa 2012 ataupun tayangan-tayangan sepanjang tahun berjalan, hampir tidak ada pengaruh signifikan regulasi penyiaran terhadap perilaku host maupun para bintang tamunya. Dalam mencermati fenomena bahwa antara regulasi yang sifatnya deduktif tidak dihayati dan dijalankan secara induktif di lapangan.

Dua kutub berseberangan kepentingan adalah televisi (produser program) berorientasi laba sebagai wujud napas kapitalistis, sementara sensor dan himbauan KPI jauh api dari panggangnya. Masyarakat dan pemirsa pada umumnya memiliki penilaian tersendiri terhadap tayangan-tayangan program, tetapi satu hal yang pasti bahwa masyarakat Indonesia memang belum cerdas memilih dan memilah acara program yang mendidik dan menjadi nilai-nilai dasar etika dan norma umum yang berlaku di masyarakat. Kondisi rumit ini diperparah oleh datangnya era konvergensi dan digital komunikasi interaktif, yang hadir mengandaikan kebebasan manusia untuk mengekspresikan dirinya. Interaksi antarindividu melampaui batas-batas geografis dan berlangsung secara simultan pada saat yang sama. Setiap ekspresi individu manusia selalu mendapatkan peneguhan dari hak individu dan hak asasi manusia universal sebagai suatu alasan klasik yang sering menjadi penghambat implementasi regulasi perilaku tayangan program. Nilai-nilai demokrasi liberal tumbuh subur di benak masyarakat negara-negara berkembang termasuk Indonesia. Kondisi tersebut mendapatkan justifikasi dari situasi munculnya era reformasi yang menghendaki “kebebasan” pers sebagai wujud era demokrasi. Dampaknya, ekspresi kebebasan hampir tanpa kontrol.

Masyarakat Indonesia dalam perjalanan sejarahnya telah mengalami dua era yang berbeda dalam penyelenggaraan hidup berbangsa dan bernegara. Di era orde lama (era Soekarno-Hatta) dikenal era demokrasi terpimpin, dan pers tampil secara sederhana karena Indonesia baru merdeka. Semua bentuk ekspresi warga negara khususnya pers, masih dalam proses mencari identitas. Memasuki era orde baru, justru ekspresi pers makin tidak mendapat tempat untuk tampil bebas. Indonesia masuk dalam era kediktatoran dan hegemoni autoritarian yang sangat memasung kebebasan pers. Momentum ini justru membuat masyarakat, khususnya dunia pers, memendam rasa frustasi ekspresi kebebasannya yang menumpuk. Jika hal-hal tersebut yang menjadi alasan berekspresi, pertanyaannya adalah dari sudut mana dunia program televisi harus memulai. Atau dengan kata lain, acuan apa yang mampu menjadi dasar pedoman dan pijakan untuk tampil secara elegan dan mendidik pemirsa atau masyarakat.

Pertanyaan-pertanyaan tersebut menjadi penting karena setelah memasuki era reformasi melepaskan diri dari kekuasaan diktator autoritarian Orde Baru selama tiga dekade, perubahan besar ekspresi kebebasan terjamin. Industri penyiaran di Indonesia mendapatkan momentum. Mimpi kebebasan terwujud, sebagai bentuk ekspresi kebebasan menyebarkan informasi. Industri pertelevisian tumbuh pesat. Data menunjukkan telah beroperasi 10 stasiun televisi swasta nasional dan ratusan televisi lokal yang ada di 33 propinsi seluruh Indonesia. Jumlah ini tidak termasuk televisi komunitas yang mencapai puluhan, ditambah satu stasiun televisi publik, Televisi Republik Indonesia (TVRI) yang melakukan siaran di Jakarta dan beberapa kota besar lain di Indonesia.

Banyaknya stasiun televisi sebagai industri penyiaran adalah suatu kenyataan bersinggungan langsung dengan dunia bisnis. Persaingan di antara media penyiaran televisi merupakan akibat derivatif yang tak mungkin dihindari. Menurut pengamatan penelitian, terjadi persaingan di antara para praktisi penyiaran dalam dunia bisnis. Kerja sama antara pebisnis kapitalis dengan media penyiaran merupakan suatu keniscayaan. Para produduser membuat program-program terbaik sesuai keinginan penonton. Bagi stasiun televisi swasta, program adalah napas kehidupan televisi. Melalui program pula penonton dihibur dan dipenuhi kebutuhannya. Dalam penayangan program itu, pihak ketiga diikutsertakan memasang iklan di stasiun televisi. Indikasi keberhasilan sebuah program ditandai dengan jumlah penonton yang banyak, dan memudahkan mendapatkan iklan, yang menjadi sumber pemasukan utama bagi stasiun televisi swasta. 
Gambaran-gambaran tersebut mendeskripsikan dua kepentingan sekaligus. Industri pertelevisian tidak dapat melepaskan diri dari kepentingan pemodal kapitalis, yang berusaha mendapatkan keuntungan sebesar-besarnya. Pada sisi lain nilai-nilai edukasi yang seharusnya dimuat selama tayangan program diabaikan. Contoh salah satu program yang sering melakukan pelanggaran terhadap regulasi penyiaran adalah program "Empat Mata” yang ditayangkan Trans7 pada 2006. Menurut catatan Komisi Penyiaran Indonesia (KPI) program "Empat Mata” sering melanggar kode etik penyiaran. Bahkan hampir semua tayangan program hiburan selama bulan puasa pun, sifat tayangnya tak ubahnya dengan bulan-bulan lain sepanjang tahun. Itu sebabnya program ini mendapat sanksi, dan kemudian mengganti nama menjadi program "Bukan Empat Mata” pada 2009. Menarik untuk diketahui bagaimana manajemen Trans7 melakukan planning, organizing, directing, dan controlling sebagai tugas utama manajemen ketika menghadapi respons dan teguran dari KPI akibat pelanggaran yang dilakukan host program.

\section{Tujuan}

Penelitian ini bersifat multidisiplin dan mengkaji persepsi manajemen Komisi Penyiaran Indonesia (KPI) dan produser program televisi Trans7 terhadap regulasi penyiaran dan penafsiran perilaku host selama penayangan program-programnya yang dianggap melanggar kode etik regulasi penyiaran televisi. Tujuan penelitian adalah mengeksplorasi lebih jauh perbandingan implementasi pedoman perilaku penyiaran.

Komisi Penyiaran Indonesia (KPI) menjadi acuan penelitian karena komisi independen ini berkewajiban mengontrol semua bentuk tayangan program televisi di Indonesia. KPI berwenang untuk memberikan penilaian bagi setiap program televisi yang ditayangkan. Komisi penyiaran mengharapkan bahwa setiap program televisi khususnya program hiburan akan senantiasa mengacu kepada kode etik regulasi penyiaran.

Sebaliknya, manajemen dan produser program televisi selalu berorientasi pada keinginan dan kebutuhan pemirsa (market oriented). Dengan kata lain, masing-masing pihak akan selalu mendahulukan kepentingannya. KPI sebagai pengendali kode etik penyiaran berpegang teguh pada undang-undang penyiaran. Sementara manajemen televisi dan produser program berupaya menarik pemirsa sebanyak-banyaknya, dengan menampilkan dan menayangkan program sesuai selera pemirsa.

\section{Keutamaan}

Penelitian mendeskripsikan sekaligus memaparkan berbagai aspek yang muncul terkait kelayakan dan kepantasan suatu program televisi disiarkan. Kebutuhan pemirsa untuk mendapatkan hiburan gratis dari penayangan program televisi merupakan momen yang diinginkan dan dibutuhkan masyarakat pemirsa. Jumlah pemirsa Indonesia yang sangat besar, merupakan "pasar" bagi stasiun televisi untuk menyajikan program terbaik, menurut keinginan penontonnya. Bagi stasiun televisi, khususnya televisi swasta, kesempatan menayangkan suatu program merupakan "peluang” bisnis yang sangat menguntungkan. Boleh jadi, demi meraih keuntungan yang sebesar-besarnya, manajemen dan produser program televisi "lupa dan lalai” untuk menyajikan program yang pantas dan layak di mata masyarakatnya.

Persoalannya terletak pada cara menafsirkan dan memaknakan suatu "aksi” dari suatu program televisi. Aksi dan perilaku host program boleh jadi mengalami tendensi yang dianggap bersebrangan dengan kebutuhan masyarakat pemirsanya dalam memberi penilaian. Melalui sudut pandang ini, manajemen dan produser program hanya mengejar "rating" televisi. Suatu aksi host program yang "menyimpang" dianggap biasa dan etis serta menarik sekaligus "menghibur" penontonnya. Akan tetapi, bagi Komisi Penyiaran Indonesia, aksi tertentu itu dianggap "vulgar" dan tidak pantas disajikan untuk ditonton masyarakat pemirsa. Inilah masalah dasar etis dan tidak etis 
menurut penilaian masing-masing pihak yang perlu dikaji lebih mendalam, agar menjadi masukan dan informasi positif terhadap perkembangan tayangan program televisi di Indonesia.

Keutamaan suatu penayangan program televisi sebagai media massa, merupakan "instrumen" dan wadah untuk pembelajaran dan proses pendidikan dalam arti luas. Bagi peneliti, program televisi adalah alat sekaligus agen pembelajaran untuk perkembangan pertelevisian di Indonesia. Jika masyarakat pemirsa adalah stakeholder utamanya, mereka berhak mendapatkan tontonan yang menarik dan layak (dalam arti yang sesungguhnya). Akan tetapi, hal itu belum tentu layak menurut penilaian Komisi Penyiaran Indonesia. Makna tafsirnya berada pada Komisi Penyiaran yang menjadi pengendali dan pengawas penyiaran program. Inilah ruang bagi peneliti untuk mendalami makna tafsir "etic" sekaligus mencari makna tafsir "emic" yang transparan dari pemaknaan suatu tayangan program televisi sebagai media massa yang menghibur pemirsanya.

Tayangan-tayangan program hiburan diharapkan menampilkan ruang bagi pemeliharaan budaya (cultural education space), yakni ruang masyarakat mendapatkan tontonan yang menghibur sekaligus mendidik. Pada tataran tertentu, ruang tontonan televisi yang menghibur itu akan berubah menjadi tradisi yang membudaya dan berbudaya Indonesia. Maka makna kultural dan tradisi seharusnya menjadi titik acuan yang perlu dikultivasi dan diseminasikan.

Tingkat pendidikan host program yang kurang memadai mungkin menjadi masalah dalam memberi penilaian tentang pantas dan tidak pantas penayangan suatu program. Terdapat gap atau jarak yang sangat mendasar dalam memaknai suatu acara televisi. Televisi sebagai media tontonan yang berinteraksi dengan pemirsa yang berjalan satu arah (one way flow communication) memberi peluang bagi produser untuk memaksakan keinginannya bagi penonton. Penonton yang dewasa dan cerdas akan mengapresiasi sekaligus memberi respons terhadap manajemen televisi untuk memberi penilaian positif atau negatif. Sebaliknya, pemirsa di Indonesia umumnya belum cerdas memilih program tayang yang mencerahkan.

Kemudahan mengakses tontonan televisi dapat berubah menjadi tradisi yang berbudaya modern namun dapat pula merusak budaya dan tradisi lokal (destructed local culture and tradition). Dalam mengakses tontonan yang berwujud berita dan hiburan, hal itu dapat memengaruhi pandangan, cara berpikir, serta perilaku masyarakat. Maka kajian ini menjadi penting untuk dilaksanakan agar Komisi Penyiaran bersama-sama masyarakat Indonesia tetap memelihara rasa nyaman menurut ukuran tradisi dan etika serta moral masyarakat yang berbudaya.

\section{Media Massa dan Komunikasi Massa}

Rodman (2012) mengatakan bahwa media massa dalam dunia yang berubah, akan menguji semua bentuk dan strukturnya termasuk televisi dan Internet, dan dengan pencapaian kecanggihan elektronik komputer, media massa memiliki kekuatan yang dasyat dalam membentuk format interaktif digital. Dengan dielaborasi secara lugas, kemajuan ilmu pengetahuan dan teknologi digital interaktif mampu secara signifikan mengubah seluruh format dan bentuk lama menjadi format dan struktur yang baru.

"Mass Media in a changing world will examine the movie, recording, radio, television, and internet industries, once again looking at their history, their current structure, and the social issues that create controversy about them. With their electronic reach, these are considered the most powerful of the media. They are also rapidly converging into one digital, interactive format."

Hal ini berarti menuntut perubahan mindset dan media literacy yang cukup untuk mampu secara elegan mengakses semua informasi yang disajikan oleh mass media termasuk televisi kepada 
pemirsanya. Kemampuan media literacy inilah yang menjadi kendala terbesar pemirsa di negaranegara berkembang termasuk Indonesia.

Pendapat Rodman diperkuat oleh Bittner R. John, bahwa mass communication is messages communicated through a mass medium to a large number of people. Atau dengan kata lain komunikasi massa adalah penyampaian sejumlah pesan melalui media massa kepada khalayak banyak. Hal ini berarti komunikasi berlangsung dan berproses secara konvergen menuju satu arah yakni dari massa yang banyak menuju tayangan program yang diselenggarakan melalui media massa. Media massa mencakup radio, televisi, Internet dan surat kabar, juga media film. Definisi ini dipertegas Vivian (2008) bahwa komunikasi massa adalah proses penggunaan sebuah media massa untuk mengirimkan pesan kepada audience yang luas untuk tujuan memberi informasi, menghibur, dan mendidik. Media massa yang yang dimaksud adalah radio, Internet, koran dan televisi. Vivian menyatakan, sama dengan komunikasi jenis lainnya, seperti komunikasi interpersonal dan komunikasi kelompok, yang tetap mengharuskan adanya pengirim pesan, maupun mereka yang menerima pesan. Namun bedanya, komunikasi massa menggunakan media massa untuk menyampaikan pesan dan jumlah penerima pesannya banyak dan beragam (Vivian, 2008). Pendapat-pendapat tersebut diperkuat Baran dan Davis (2010) yang mengatakan komunikasi massa adalah ketika sebuah organisasi menggunakan teknologi sebagai sebuah media untuk berkomunikasi dengan khalayak yang besar. Hal penting yang harus ada dalam komunikasi massa adalah digunakannya teknologi sebagai media untuk menyampaikan pesan (Baran \& Davis, 2010). Jika dielaborasi lebih jauh, dapat dilihat bahwa semua ahli komunikasi massa hampir berpendapat sama yakni harus ada pesan dan pesan disampaikan melalui media yang ditujukan kepada khalayak banyak dan bergerak satu arah.

\section{METODE}

Metode penelitian induktif menggunakan pendekatan qualitative exploratory dan in-depth interview, menerapkan multidisiplin ilmu, dan mengacu pada model-model teori ilmu sosial dan ilmu komunikasi. Pendekatan metode kualitatif induktif adalah suatu proses penelitian dan pemahaman yang berdasarkan pada metodologi yang menyelidiki suatu fenomena sosial dan masalah yang terjadi. Sedangkan qualitative exploratory adalah pendekatan untuk memberi gambaran kompleks dan melakukan wawancara mendalam sekaligus mengeksplorasi masalah secara langsung di lapangan maupun menggali masalah langsung dari narasumber terpercaya, meneliti kata-kata dalam dokumen, laporan terinci dari pandangan partisipan, dan melakukan studi pada situasi yang alami (Creswell, 2007). Metode kualitatif merupakan prosedur penelitian yang menghasilkan data deskriptif berupa kata-kata tertulis maupun lisan dari orang-orang dan perilaku yang diamati.

Penelitian kualitatif dilakukan pada kondisi alamiah dan bersifat penemuan. Dalam penelitian kualitatif, peneliti adalah instrumen kunci. Oleh karena itu, peneliti harus memiliki bekal teori dan wawasan yang luas agar dapat bertanya, menganalisis, dan mengonstruksi objek yang diteliti menjadi lebih jelas. Penelitian ini lebih menekankan pada makna dan terikat nilai. Penelitian kualitatif digunakan jika masalah belum jelas, untuk mengetahui makna yang tersembunyi, untuk memahami interaksi sosial, untuk mengembangkan teori, untuk memastikan kebenaran data, dan meneliti sejarah perkembangan masalah. Metode ini diharapkan dapat mengkaji pengaruh terpaan media televisi yang bermuara pada program yang ditayangkan. Selain itu, diharapkan dapat mengkaji pengaruh terpaan media televisi terhadap sudut pandang masyarakat multikultural dalam kaitannya dengan pertahanan mental masyarakat.

Penelitian merefleksikan secara mendalam pengaruh tayangan program melalui media televisi terhadap masyarakat Indonesia pada umumnya. Identifikasi dan analisis mendalam dilakukan terhadap Komisi Penyiaran Indonesia (KPI), manajemen televisi, produser, dan host program siaran. 
Perkembangan media televisi, khususnya televisi swasta dalam konteks kehidupan sosial masyarakat dan praktik budaya bertelevisi yang kian marak dan beragam, makin mengukuhkan eksistensi paradigma kualitatif. Kemampuannya menghasilkan produk analisis yang mendalam selaras dengan setting-nya diakui sebagai paradigma yang patut dalam rangka menghadirkan refleksi bagi kajian ilmu komunikasi dan ilmu sosial lainnya.

Penelitian lapangan menjadi ciri khas ilmu sosial termasuk ilmu komunikasi. Penelitian melakukan kegiatan pengamatan dengan mempelajari segala hal mengenai penayangan program untuk mendeskripsikan kebiasaan host program yang dianggap menyimpang menurut persepsi Komisi Penyiaran Indonesia. Tujuan utama aktivitas ini adalah memahami sudut pandang Komisi Penyiaran Indonesia (KPI) dan pandangan manajemen serta produser program televisi swasta, khususnya Trans7 sebagai subjek kajian.

\section{HASIL DAN PEMBAHASAN}

Hal mendasar yang dikaji adalah penafsiran Komisi Penyiaran Indonesia (KPI) bahwa perilaku host program-program tertentu dari TV swasta secara umum hanya mengejar rating. Trans7 misalnya, dinilai melanggar kode etik penyiaran program berulang kali. Pertanyaan, apa yang menjadi dasar etis dan alasan fundamental bahwa ucapan dan perilaku tertentu dari host program melanggar kode etik dan regulasi penyiaran. Pertanyaan ini menjadi penting dan mendasar karena KPI sebagai ethical gatekeeper dalam menegakkan etika dan kekuatan moral, tidak sepenuhnya sudah benar. Maka manajemen dan produser program perlu menyikapi penilaian KPI sebagai pelaksana regulasi di lapangan. Masalah selanjutnya adalah pedoman perilaku penyiaran tidak langsung disosialisasikan kepada semua host yang terkait program-program hiburan. Menurut pengamatan peneliti terjadi gap atau jurang yang sangat terjal antara regulasi yang sifatnya deduktif idealis dengan pelaksana siaran program yang sifatnya induktif di lapangan. Jurang pemisah ini nampaknya tidak tersentuh oleh karena rintangan kepentingan kapitalis televisi, jauh melampaui kekuatan KPI yang berjalan sendiri. Dengan kata lain, semua host program hiburan berjalan sesuai selera pasar. Satu hal mendasar adalah sumberdaya manusia yang ada di Komisi Penyiaran Indonesia (KPI) nampaknya masih kurang kompeten.

Hal mendasar lain yang dikaji adalah cara KPI memberi makna pada pasal-pasal undangundang penyiaran, dan bagaimana mendekatkan penafsiran pasal-pasal dengan kenyataan di lapangan. Fokusnya pasal undang-undang penyiaran yang hanya secara afirmatif mengatakan etis atau tidak etis sebuah program ditayangkan. Pantas atau tidak pantas sebuah aksi dari host program harus dimaknai dan ditanggapi selama penayangan program berlangsung. Tenaga-tenaga pengawas dan pengontrol program siaran yang ada di kantor KPI menurut pengamatan peneliti hampir kebanyakan wanita yang memiliki persepsi dan bentukan mindset yang berjalan linear. Petugas-petugas pengontrol program siaran nampak homogen dilihat dari anutan norma dan kapasitas dalam memberi penilaian.

Komisi Penyiaran Indonesia (KPI) adalah lembaga independen, yang tidak mewakili etnis, suku atau agama tertentu, tetapi mindset dan panutan norma yang mereka miliki, nampaknya berjalan linear. Dalam istilah Freud, pegawai-pegawai pengontrol acara tayang program televisi nampaknya lebih dominan faktor superego atau dalam istilah bahasa Jerman, faktor Uberich melampaui faktor Id. Intervensi faktor ego tak nampak pada postur-postur pelaksana pengontrol program. Peneliti berpersepsi bahwa norma-norma etis yang mengalir dalam mindset para pegawai pengontrol berjalan datar. Mereka tidak masuk menelisik lebih jauh kompleksitas interaksi masyarakat global yang makin terbuka. 


\section{Teori McLuhan: Media adalah Pesan}

Semua host program televisi swasta sangat heterogen. Heterogen di sini adalah latar belakang kebiasaan, budaya, suku, agama, dan tingkat pendidikan yang beragam, yang dipersiapkan untuk menyampaikan program-program televisi, termasuk program hiburan untuk memenuhi kebutuhan pemirsa. Masalahnya, program televisi adalah pesan itu sendiri. Dan pesan melalui media televisi berpengaruh signifikan terhadap sikap masyarakat Indonesia yang masih memegang kuat normanorma, adat dan tradisi serta budaya yang paternalistik. McLuhan berargumentasi: "the medium is the message." Menurutnya, yang terpenting dari media televisi adalah orang melihat dan mendengar langsung. McLuhan melanjutkan: "The effects of technology do not occur at the level of opinions or concepts, but alter sense ratios or patterns of perception steadily and without any resistance." McLuhan menyatakan bahwa media secara mendalam memengaruhi cara kita berpikir dan memaknai kenyataan (dalam Berger, 1995). McLuhan dengan teliti membedakan watak print media dan electronic media dalam hal: sensibilitas dan perspektifnya. Pendekatan print media adalah mengklasifikasi data, sementara electronic media adalah berupaya mempolakan perilaku dengan melihat langsung sehingga mampu menimbulkan emosi pemirsa.

Efektifnya media massa, khususnya media televisi melampaui media-media lain karena televisi merupakan satu-satunya media massa elektronik yang mampu melibatkan seluruh panca indra dalam menarik perhatian penggunanya. Dengan kata lain, tingkat sensibilitasnya melampaui media massa lainnya. Produser dan host program televisi khusus host program hiburan seakan berjalan tanpa memerhatikan nilai-nilai yang tertuang dalam Pedoman Perilaku Penyiaran dan Standar Program Siaran (P3-SPS). Hal tersebut disebabkan dua hal. Pertama, host program memahami isi pedoman perilaku penyiaran namun mengabaikannya demi mengejar target kenaikkan rating. Kedua, host program tidak memahami nilai-nilai pedoman perilaku penyiaran karena tidak pernah membacanya atau tidak pernah mengetahuinya. Hal ini dapat melahirkan reaksi publik yakni, mempertanyakan peran manajemen KPI yang tidak berupaya menanamkan nilai-nilai P3-SPS kepada manajemen televisi dan terutama kepada produser beserta host program. Kenyataan di lapangan membuktikan bahwa host program melaksanakan tugasnya sesuai keinginan manajemen dan keinginan pengguna atau masyarakat penonton (pemirsa).

Berhubungan dengan ucapan dan perilaku host program televisi yang menonjolkan unsur seks juga masih kabur dalam memberikan penilaian. Menerjemahkan pasal dan ayat-ayat Pedoman Perilaku Penyiaran (P3) pada situasi tayang program berlangsung tentulah tidak adil memetik setiap ucapan atau gerak tubuh terpisah dari konteks program. Dalam wawancara dengan Direktur Utama Trans7, peneliti mendapatkan jawaban atas masalah penampilan host program bukan tidak mengikuti regulasi penyiaran, melainkan mereka justru mengadopsi apa yang diinginkan oleh pemirsa sebagai pasarnya. Kecendrungan dan keinginan pemirsa menurut manajemen Trans7 adalah sesuai hati nurani. Hal itu berarti yang penting keinginan dan kebutuhan pasar terpenuhi. Pemirsa televisi yang dimaksud mencakup semua pemirsa. Di sini terletak pokok masalah karena melibatkan anak-anak dan remaja yang menurut takaran budaya dianggap tidak etis dan melanggar norma moral.

Apakah sebaiknya membiarkan anak-anak dan remaja untuk menyeleksi dan menentukan pilihan tontonan sesuai keinginannya atau menakar tontonan sesuai keinginan orang dewasa tentang etis dan tidak etis. Hal ini menjadi penting terkait kondisi masyarakat global seperti yang dinyatakan McLuhan yaitu masyarakat sudah menyatu bersama setiap saat dalam ruang yang sama (global village). Implikasinya, sebagai manusia dewasa, seseorang dapat melarang anak-anak dan remaja untuk tidak menonton apa yang dianggap tidak etis dan tak bermoral pada ruang publik melalui televisi. Namun pada saat yang sama, kaum remaja dapat mengakses setiap tontonan yang berasal dari pelosok dunia mana saja. Platform alam sadar kaum remaja tidak mungkin sama dengan yang dipikirkan dan yang dialami orang dewasa pada masa lampau. Orang-orang dewasa termasuk dalam golongan digital imigrant. Sebaliknya, anak-anak dan kaum remaja kota khususnya adalah pemilik dan penghuni era digital. Pengalaman mereka adalah suatu keniscayaan untuk terpisah dari teknologi 
digital. Oleh karena itu, pembelajaran media literacy menjadi sangat penting agar budaya menyeleksi tontonan menjadi milik dan habit kaum remaja maupun anak-anak. Pada tataran berpikir seperti itu, harus ada kesepakatan bersama, bahwa budaya nasional seharusnya mengadopsi habit yang sama dalam takaran norma yang sama pula. Oleh karena takaran norma yang sama dan diikuti dengan tulus, khusus para host program televisi, dalam pembelajaran bersama akan menghasilkan dataran budaya yang sama, yang muncul sebagai peradaban bangsa dan menjadi investasi modal bersama pula.

Rodman (2012) menambahkan:

"The Digital Era has ushered in a rethinking of media responsibility that might be called the ethics of unlimited information. Pornography and hate sites flourish on the web, and several 24-hour cable news services have shown that no contemporary information, no matter how lurid or embarrasing, can be hidden from children. For example, the 2010 Ariel Peterpan and two women, Luna Maya and Cut Tari affair, created daily ethical quandaries. The question is, should information about the affair, in all its graphic detail, be placed on the Net for all to access?”

Secara lugas dapat dikatakan bahwa pada era digital ini masyarakat digiring untuk memikirkan kembali peran dan tanggung jawab media tentang etika era informasi tak terbatas ini, pornografi dan kebencian memenuhi ruang-ruang Internet, dan selama 24 jam pelayanan informasi melalui berita cable telah menunjukan informasi yang nampak, apakah memikat atau memalukan, dapat disembunyikan dari pandangan anak-anak. Sebagai contoh, skandal seks Ariel bersama dua wanita yakni Luna Maya dan Cut Tari telah menciptakan kebingungan-kebingungan etis setiap hari. Pertanyaannya adalah, apakah informasi tentang skandal seks tersebut, yang masih bersarang di Internet, boleh diakses remaja dan anak-anak.

Hal ini bermakna bahwa seorang tidak mampu untuk melakukan proteksi terhadap tontonan remaja. Oleh karena itu menjadi sia-sia jika tontonan yang hanya berwujud gerakan erotis dan bahasa tubuh selalu harus disembunyikan dari pandangan remaja dan anak-anak. Jika itu yang terjadi, daya self-protective teenagers tidak akan teruji untuk menyeleksi tontonan yang menurut mereka etis atau tidak etis karena selalu ditentukan dari yang merasa lebih tua atau yang merasa bernorma dan berbudaya. Dengan demikian, pertanyaan etis atau tidak etis akan selalu memunculkan berita dan tayangan yang ditanggapi KPI tunduk pada Pedoman Perilaku penyiaran secara parsial yang tidak kontekstual. Di sini persoalan etis dan tidak etis sebuah tayangan program televisi dinilai secara harfiah. Persoalan ini menjadi penting karena pengaruh budaya global akan makin intens diakses oleh siapa saja yang lahir pada era digital ini.

Konflik kepentingan yang berseberangan terjadi ketika televisi sebagai pencipta program tontonan masyarakat yang berorientasi profit menaikkan rating tayang dan KPI sebagai ethical gatekeeper perlu melakukan kompromi dengan referensi pada kenyataan riil kebutuhan masyarakat pada era digital ini. Implikasinya adalah bahwa implementasi Pedoman Perilaku Penyiaran KPI dengan acuan pedoman etika dan norma yang berkembang di masyarakat, sebaiknya beradaptasi dengan kenyataan berita dan tontonan yang muncul 24 jam melalui media sosial atau website yang mudah diakses. Jika tidak demikian, ayat-ayat dalam pasal P3 hanya akan menjadi tulisan norma dan etika yang tak bermakna dan tidak dapat diterjemahkan dalam perilaku host program maupun tayangan yang dianggap vulgar di mata Komisi Penyiaran Indonesia. Hal itu mengingat undangundang penyiaran pun belum memadai untuk memproteksi tontonan yang mudah diakses melalui Internet atau berita cable yang hadir selama 24 jam. Pada era global yang sangat kompetitif para pemilik modal (capitalist) akan selalu memihak pemilik televisi untuk mendapatkan keuntungan sebesar-besarnya. 


\section{SIMPULAN}

Eksistensi Komisi Penyiaran Indonesia (KPI) sebagai Ethical Gatekeeper yang mengawal semua bentuk tayangan dan siaran dapat mengacu kepada Pedoman Perilaku Penyiaran (P3) dan Standar Program Siaran (SPS) sebaiknya juga melihat budaya global sebagai faktor eksternal yang tidak mungkin dihindari pengaruhnya. Artinya KPI dapat menimba acuan dasar dari P3-SPS untuk diimplementasikan dan diterjemahkan oleh semua host program tanpa mengabaikan dataran budaya global sebagai salah satu acuan. Dengan demikian, tayangan yang kontekstual seharusnya dapat dibaca dalam rangka adaptasi budaya global pada era informasi digital ini. Ini adalah kesulitan KPI dalam mengadaptasi budaya global sebagai alternatif lain dalam kaitan dengan proses akulturasi dan inkulturasi budaya asing. Hal itu yang dimaksudkan dengan implementasi kontekstual P3 pada era global ini. Rumit rasanya jika sumber daya manusia yang ada di KPI yang terlihat berpikir datar mampu mengadaptasi tayangan program secara kontekstual.

Oleh karena itu, para pengontrol program masih berpikir parsial, harus berpikir inklusif untuk melihat masalah tayangan secara kontekstual di era global ini. Inilah yang disebut Rodman sebagai the ethics of unlimited information, yang harus diperhatikan sebagai masukan yang sangat berharga dalam rangka menerapkan pasal dan ayat-ayat yang menurut norma dan etika masyarakat Indonesia patut atau tidak patut. Mana mungkin seorang berdiri parsial dalam menerapkan etika dan norma masyarakat, sementara pada saat yang sama kaum remaja dan anak-anak sudah mampu mengakses informasi lain yang jauh lebih vulgar dari yang dilarang. Jika kondisi ini yang dipertahankan, cepat atau lambat akan lahir generasi-generasi baru yang bingung (ethical quandary teenagers). Sebagai manusia pembelajar seorang harus yakin dengan pernyataan McLuhan tentang kehadiran di global village, bahwa dia tidak mungkin menyembunyikan diri dan menghindarkan diri dari berita dan informasi yang mengikuti di ruang-ruang pribadi, di manapun dan kapan pun.

Sebagai pemilik modal yang mengendalikan media penyiaran yang berorientasi profit, seharusnya mengimplementasikan P3 sebagai dasar pijakan dalam melakukan aktivitas penyiaran. Namun dalam kenyataan riil, manajemen televisi dan produser bersama host program belum menghayati dan melaksanakan pedoman perilaku penyiaran. Hal ini terbukti dari hasil wawancara dengan Direktur Utama salah satu televisi swasta (Trans7). Dalam wawancara mendalam terkait beberapa teguran dari KPI, jawaban yang diberikan adalah bersifat normatif sekaligus dikembalikan kepada hati nurani. Dalam konteks jawaban ini, peneliti berasumsi bahwa pemilik televisi mengikuti keinginan dan kebutuhan pasar atau pemirsa televisi. Hal ini dapat dipahami karena berkorelasi positif dengan persaingan yang ketat di antara media-media penyiaran. Berarti juga, terdapat kecendrungan untuk selalu meningkatkan laba. Dengan demikian, keinginan dan kebutuhan pemirsa akan hiburan yang kreatif, menjadi modal utama dalam menayangkan suatu program. Dalam konteks ini menurut interpretasi Peneliti adalah bahwa host program bersama produser sebetulnya lebih terbuka dan menampilkan hiburan yang sifatnya kontekstual dalam mengadopsi budaya global. Pemahaman manajemen, produser dan host program terhadap proses inkulturasi budaya sebetulnya mengalami kemajuan (adaptive culture). Dengan kata lain, pengaruh budaya asing atau eksternal tidak mungkin diabaikan dalam rangka hidup bersama pada era global. Dalam konteks ini pula, pemahaman akan pernyataan McLuhan bagi pemilik televisi sangat relevan, yakni berada bersama dalam suatu wilayah yang sama, global village. Manajemen televisi sebetulnya melihat pernyataan Rodman: the ethical of unlimited information meskipun mereka tidak secara harfiah melihatnya sebagai masukan dalam rangka memproduksi suatu program yang kreatif menurut perspektif pasar atau pemirsa. Akan tetapi, pemahaman akan hidup bersama pada era global menjadi salah satu acuan dasar menghadapi persaingan yang kompetitif.

Bagaimana dengan pasar atau pemirsa yang teridentifikasi dalam dua kategori, yakni pemirsa yang berorientasi masyarakat global dan pemirsa yang digolongkan tradisional atau pemirsa yang 
masih terikat kuat dengan etika dan norma-norma lokal. Hal ini menjadi penting karena mayoritas pemirsa Indonesia masih tergolong yang disebutkan terakhir. Untuk mengakomodasi kebutuhan pemirsa golongan kedua (tradisional), maka hal yang perlu dilakukan adalah memberi penyadaran dan sosialisasi tentang era digital yang tidak mungkin dihindari oleh masyarakat dari negara-negara berkembang termasuk Indonesia. Ini adalah proses pembelajaran dalam rangka media literacy kepada masyarakat yang heterogen seperti Indonesia.

Penelitian menemukan fakta bahwa masyarakat yang tergolong menganut norma-norma ketat ternyata dalam kesehariannya juga bebas mengadopsi informasi luar yang bersifat vulgar. Hal itu terbukti dari jawaban mereka dalam menyikapi pengaruh budaya luar. Umumnya jawaban mereka cukup permisif bahkan menjadi penonton atau pernah menonton tayangan vulgar, padahal mereka sebetulnya menggunakan atribut sebagai petunjuk identitas beragama. Jadi sebetulnya isi otak kaum remaja tidak seperti yang disaksikan melalui bungkusnya. Untuk hal ini hanya ada satu cara yaitu dengan memberi penyadaran pertama-tama di rumah dan lingkungan masyarakat dan kedua, filter atau proteksi di sekolah atau tempat belajar melalui pendidikan karakter atau membangun karakter selain doktrin agama yang diperoleh di rumah dan sekolah.

\section{DAFTAR PUSTAKA}

Baran, J. S., \& Davis, D. K. (2010). Teori Komunikasi Massa: Dasar, Pergolakan, dan Masa Depan. Jakarta: Salemba Humanika.

Berger, A. A. (1995). Essentials of Mass Communication Theory. Sage Publication.

Creswell, J. (2007). Qualitative Inquiry \& Research Design; dan Quantitative Approaches. Jakarta: UI Press.

Komisi Penyiaran Indonesia (KPI). (2012). Pedoman Perilaku Penyiaran dan Standar Program Siaran (P3SPS Tahun 2007, 2010, 2012). Jakarta.

Republik Indonesia. (2010). Peraturan Komisi Informasi Nomor 1 Tahun 2010 Tentang Standar Layanan Informasi Publik.

(2010). Peraturan Komisi Informasi Nomor 2 Tahun 2010 Tentang Prosedur Penyelesaian Sengketa Informasi Publik.

Rodman. (2012). Mass Media in a Changing World. New York: McGraw-Hill.

Vivian, J. (2008). Teori Komunikasi. Jakarta: Kencana. 